\title{
PENTINGNYA KECERDASAN EMOSIONAL DALAM PEMBELAJARAN
}

\author{
Kadeni \\ Dosen STKIP PGRI BLITAR \\ denikdk@gmail.com
}

\begin{abstract}
:
Learning not only as atransfer of knowledge alone but is an activity under taken untu teachers develop the potential of students as a whole to achieve change for the better. Teachers than intellectual understanding must also be able to understand the emotional intelligence of students. Emotional intelligence is the ability to regulate one's emotional life within telligence, emotion and disclosure of maintaining harmony throughself-awareness, self-control, self-motivation, empathy and social skills.

It must be understood if students only have high academic intelligence, they tend to have an unwarranted sense of restless, overlycritical, fussy, tend to with draw, seemed cool and less likely to express resent mentan danger appropriately if not supported with emotional intelligence, then the people is often asource of problems. Students who have high intelligence but low emotional intelligence level ittends to be seen as a hard-nosed, hard to get along, easily frustrated, do not easily trust others, not sensitive to environmental condition sand tend to despair when experiencing stress. The opposite condition, experienced by those who have the intelligence level of the average but has high emotional intelligence. There fore it is time all the teachers in the learning does not only focus on the intellectual but emotional intelligence of students should be a concern that they can achieve success in living life to come.
\end{abstract}

Key words: emotional intelligence, learning

\section{PENDAHULUAN}

Pendidikan merupakan suatu usaha atau kegiatan yang dijalankan dengan sadar, sengaja, teratur dan terencana untuk mengubah atau mengembangkan potensi dan perilaku yang diinginkan. Sekolah sebagai lembaga pendidikan formal merupakan salah satu sarana dalam rangka pencapaian tujuan pendidikan tersebut. Melalui sekolah, siswa dapat belajar berbagai macam hal yang tekait dengan potensi diri dan pengalaman hidup.

Dalam pendidikan formal, kegiatan belajar diharapkan terjadi adanya perubahan yang sifatnya positif sehingga pada tahap akhir akan mempunyai keterampilan, kecakapan dan pengetahuan baru sebagai bekal mengarungi hidup di masyarakat. Salah satu hasil dari proses belajar tersebut tercermin dalam bentuk prestasi belajar yang dicapainya. Namun dalam upaya meraih prestasi belajar yang memuaskan dibutuhkan proses belajar.Proses belajar di sekolah adalah proses yang sifatnya kompleks dan menyeluruh. Banyak orang yang berpendapat bahwa untuk meraih prestasi yang tinggi dalam belajar, seseorang harus memiliki kecerdasan intelektualyang tinggi, karena inteligensi merupakan bekal potensial yang akan memudahkan dalam belajar dan pada gilirannya akan menghasilkan prestasi belajar yang optimal. 
Dalam kegiatan proses belajar mengajar di sekolah kenyataannyasering terjadi siswa tidak dapat meraih prestasi belajar yang sesuai dengan kemampuan inteligensinya. Tidaksedikit siswa yang mempunyai kemampuan inteligensi tinggi tetapi memperoleh prestasi belajar relatif rendah, sebaliknya ada juga siswa yang walaupun kemampuan inteligensinya relatif rendah, mampu meraih prestasi belajar yang relatif tinggi. Hal tersebut menunjukkan bahwa tingkat inteligensi bukan merupakan satusatunya faktor yang menentukan keberhasilan seseorang, karena ada faktor lain yang mempengaruhi. Menurut Goleman (2000), menyatakan bahwa kecerdasan intelektual (IQ) hanya menyumbang $20 \%$ bagi kesuksesan, sedangkan $80 \%$ adalah sumbangan faktor kekuatan-kekuatan lain, diantaranya adalah kecerdasan emosional (EQ) yakni kemampuan memotivasi diri sendiri, mengatasi frustasi, mengontrol desakan hati, mengatur suasana hati (mood), berempati serta kemampuan bekerja sama.

Kedua inteligensi tersebutIQ dan EQdalam kegiatan proses belajar siswa sangat diperlukan. Kecerdasan intelektual saja tidak dapat berfungsi dengan baik tanpa didukung oleh kecerdasan emosional dalam menerima dan memahami mata pelajaran yang disampaikan guru di sekolah. Namun biasanya kedua inteligensi itu saling melengkapi. Keseimbangan antara kecerdasan intelektual dan kecerdasan emosional merupakan kunci keberhasilan belajar siswa di sekolah (Goleman, 2002). Pendidikan di sekolah bukan hanya perlu mengembangkan rational intelligence yaitu model pemahaman yang lazimnya dipahami siswa saja, melainkan juga perlu mengembangkan kecerdasan emosionalsiswa.

\section{KECERDASAN EMOSIONAL}

Kecerdasan merupakankemampuan seseorang untuk melakukan sesuatu. Pada umumya pemahaman kemampuan manusia seringkali hanya diukur dari segi kognitif semata, yaitu hal-hal yang dapat diukur dengan angka. Sebagai contoh adalah bagaimana ketika anak-anak menerima buku rapor. Banyak orang yang mengambil kesimpulan bahwa anak tersebut cerdas, apabila nilai-nilai yang diperoleh sangat membanggakan dan juga sebaliknya. Pemahaman lebih sempit, pada anak usia dini kecerdasan hanya diukur dari kelancaran baca-tulis, kelancaran berbicara dan berhitung.Namun dalam kenyataannya bahwa kecerdasan atau kemampuan manusia sebenarnya sangat beragam.

Kata emosi berasal dari bahasa latin, yaitu emovere, yang berarti bergerak menjauh. Arti kata tersebut menyiratkan bahwa kecenderungan bertindak merupakan hal mutlak dalam emosi. Menurut Goleman (2002) emosi merujuk pada suatu perasaan dan pikiran yang khas, suatu keadaan biologis dan psikologis dan serangkaian kecenderungan untuk bertindak. Emosi pada dasarnya adalah dorongan untuk bertindak. Biasanya emosi merupakan reaksi terhadap rangsangan dari luar dan dalam diri individu. Sebagai contoh emosi gembira mendorong perubahan suasana hati seseorang, sehingga secara fisiologi terlihat tertawa, emosi sedih mendorong seseorang berperilaku menangis.

Goleman (2000) mengemukakan beberapa macam emosi, yaitu:
a. Amarah
: beringas, mengamuk, benci, jengkel, kesal hati
b. Kesedihan
: pedih, sedih, muram, suram, melankolis, mengasihi diri, putus asa
c. Rasa Takut
: cemas, gugup, khawatir, was-was, perasaan takut sekali waspada, tidak tenang, ngeri
d. Kenikmatan : bahagia, gembira, riang, puas, riang, senang, terhibur, 


$\begin{array}{ll} & \text { bangga } \\ \text { e. Cinta } & \text { : penerimaan, persahabatan, kepercayaan, kebaikan hati, } \\ & \text { rasa dekat, bakti, hormat, kemesraan, kasih } \\ \text { f. Terkejut } & : \text { terkesiap, terkejut } \\ \text { g. Jengkel } & : \text { hina, jijik, muak, mual, tidak suka } \\ \text { h. Malu } & : \text { malu hati, kesal }\end{array}$

Menurut Goleman (2002), kecerdasan emosional adalah kemampuan seseorang mengatur kehidupan emosinya dengan inteligensi (to manage our emotional life with intelligence); menjaga keselarasan emosi dan pengungkapannya (the appropriateness of emotion and its expression) melalui keterampilan kesadaran diri, pengendalian diri, motivasi diri, empati dan keterampilan sosial.

Mengingat pentingnya kecerdasan emosional untuk menunjang hasil belajar peserta didik, maka pengetahuan tentang kecerdasan emosional penting untuk dimiliki oleh setiap guru agar mampu mengembangkan kecerdasan emosional peserta didik. Peserta didik yang memiliki kecerdasan emosional dapat mengendalikan dirinya dengan baik dalam mengikuti proses pembelajaran dan memiliki kesadaran yang tinggi untuk belajar. Hal inilah yang menjadi modal besar bagi peserta didik untuk meraih hasil belajar dengan standar tinggi dalam berbagai hal, baik akademik maupun non akademik. Kecerdasanemosi dapat menempatkan emosi seseorangpadaporsi yang tepat,memilahkepuasandanmengatursuasanahati.Koordinasi suasana hatiadalahintidari hubungan social yang baik.Apabila seseorang pandai menyesuaikan diri dengan suasana hati individu yang lain atau dapat berempati, orang tersebut akan memiliki tingkat emosionalitas yang baik dan akan lebih mudah menyesuaikan diri dalam pergaulan sosial serta lingkungannya. Kecerdasan emosi sebagai suatu kecerdasan social yang berkaitan dengan kemampuan individu dalam memantau baik emosi dirinya maupun emosi orang lain, dan juga kemampuannya dalam membedakan emosi dirinya dengan emosi orang lain, dimana kemampuan ini digunakan untuk mengarahkan pola piker dan perilakunya".

Sejalan dengan itu, Robert dan Cooper (Ginanjar,2001) mengungkapkan bahwa kecerdasan emosi adalah kemampuan merasakan, memahami dan secara efektif menerapkan daya dan kepekaan emosi sebagai sumber energi, emosi, koneksi dan pengaruh yang manusiawi. Individu yang mampu memahami emosi individu lain,dapat bersikap dan mengambil keputusan dengan tepat tanpa menimbulkan dampak yang merugikan kedua belah pihak. Emosi dapat timbul setiap kali individu mendapatkan rangsangan yang dapat mempengaruhi kondisi jiwa dan menimbulkan gejolak dari dalam. Emosi yang dikelola dengan baik dapat dimanfaatkan untuk mendukung keberhasilan dalam berbagai bidang karena pada waktu emosi muncul, individu memiliki energi lebih dan mampu mempengaruhi individu lain. Segala sesuatu yang dihasilkan emosi tersebut bila dimanfaatkan dengan benar dapat diterapkan sebagai sumber energy yang diperlukan untuk menyelesaikan tugas mempengaruhi orang lain dan menciptakan hal-hal baru.

Berdasarkan pendapat para ahli diatas dapat disimpulkan bahwa yang dimaksud 
kecerdasan emosi adalah kemampuan merasakan dan memahami secara lebih efektif terhadap daya kepekaan emosi yang mencakup kemampuan memotivasi diri sendiri atau orang lain, pengendalian diri, mampu memahami perasaan orang lain dengan efektif, dan mampu mengelola emosi yang dapat digunakan untuk membimbing pikiran untuk mengambil keputusan yang terbaik.

Seseorang yang mempunyai kecerdasan emosional yang baik akan dapat dikenali melalui lima komponen dasar (Goleman, 1998), yaitu sebagai berikut : 1) Selfawareness (pengenalan diri), yaitu mampu mengenali emosi dan penyebab dari pemicu emosi tersebut. 2)Self-regulation (penguasaan diri), yaitu seseorang yang mempunyai pengenalan diri yang baik dapat lebih terkontrol dalam membuat tindakan agar lebih hati-hati. 3) Self-motivation (motivasi diri), yaitu ketika sesuatu berjalan tidak sesuai dengan rencana, seseorang yang mempunyai kecerdasan emosional tinggi tidak akan bertanya "Apa yang salah dengan saya atau kita?". Sebaliknya ia bertanya "Apa yang dapat kita lakukan agar kita dapat memperbaiki masalah ini?".4) Empathy (empati), yaitu kemampuan untuk mengenali perasaan orang lain dan merasakan apa yang orang lain rasakan jika dirinya sendiri yang berada pada posisi tersebut.5)Effective Relationship (hubungan yang efektif), yaitu dengan adanya empat kemampuan tersebut, seseorang dapat berkomunikasi dengan orang lain secara efektif. Kemampuan untuk memecahkan masalah bersama-sama lebih ditekankan dan bukan pada konfrontasi yang tidak penting yang sebenarnya dapat dihindari. Orang yang mempunyai kemampuan intelegensia emosional yang tinggi mempunyai tujuan yang konstruktif dalam pikirannya.Seseorang yang tidak mempunyai kecerdasan emosional yang tinggi dapat ditandai dengan hal-hal berikut: mempunyai emosi yang tinggi, cepat bertindak berdasarkan emosinya, dan tidak sensitif dengan perasaan orang lain. Orang yang tidak mempunyai kecerdasan emosional tinggi, biasanya mempunyai kecenderungan untuk menyakiti dan memusuhi orang lain.

Dalam kegiatan pembelajaran, siswa yang mempunyai kecerdasan emosional yang tinggi sangat diperlukan, terlebih dalam kegiatan kelompok untuk mencapai tujuan yang sudah ditetapkan. Oleh karenaitu, para orang tua dan para guru harus memupuk kecerdasan emosional sejak dini. Orang-orang yang sering bertindak ceroboh, tanpa berfikir panjang, tidak memiliki empati dan kurang bersabar merupakan orang-orang yang memiliki tingkat kecerdasan emosional rendah. Rendahnya tingkat kecerdasan emosional, tidak hanya membawa petaka bagi dirinya sendiri, tetapi juga sangat membahayakan orang lain dan lingkungannya.

Tingkat emosi sangat mempengaruhi kehidupan manusia, ketika dia mengambil keputusan tidak jarang keputusan yang diambil melalui emosinya. Jarang terjadi keputusan yang diambil seseorang murni dari pemikiran rasionya (akalnya), karena seluruh keputusannya memiliki warna emosional. Jika diperhatikan keputusankeputusan yang diambil seseorang, ternyata keputusannya lebih banyak ditentukan oleh emosinya daripada akal sehatnya. Kecerdasan Emosional diukur dari kemampuan mengendalikan emosi dan menahan diri. Kemampuan mengendalikan emosi dan menahan diri disebut sabar. Orang yang sabar adalah orang yang paling tinggi kecerdasan emosionalnya, biasanya tabah dalam menghadapi kesulitan. Ketika belajar orang ini tekun, memiliki empati yang tinggi, tanggap terhadap lingkungan sosialnya, berdisiplin dan bertanggung jawab, berhasil mengatasi berbagi gangguan dan tidak memperturutkan emosinya serta dapat mengendalikan perilakunya dan emosinya.

\section{PEMBELAJARAN}


Pembelajaran adalah proses interaksi peserta didik dengan pendidik dan sumber belajar pada suatu lingkungan belajar. Pembelajaran merupakan bantuan yang diberikan pendidik agar dapat terjadi proses pemerolehan ilmu dan pengetahuan, penguasaan kemahiran dan tabiat, serta pembentukan sikap dan kepercayaan pada peserta didik. Dengan kata lain, pembelajaran adalah proses untuk membantu peserta didik agar dapat belajar dengan baik. Proses pembelajaran dialami sepanjang hayat seorang manusia serta dapat berlaku dimana pun dan kapan pun. Pembelajaran mempunyai pengertian yang mirip dengan pengajaran, walaupun mempunyai konotasi yang berbeda. Pembelajaran adalah pemberdayaan potensi peserta didik menjadi kompetensi. Kegiatan pemberdayaan ini tidak dapat berhasil tanpa ada orang yang membantu.

Sanjaya (2008) menyatakan bahwa pembelajaran merupakan proses kerja sama antara guru dan siswa dalam memanfaatkan segala potensi dan sumber yang ada, baik potensi yang bersumber dari dalam diri siswa seperti minat, bakat, dan kemampuan dasar yang dimiliki, termasuk gaya belajar dan potensi yang ada di luar diri siswa seperti lingkungan, sarana, dan sumber belajar sebagai upaya untuk mencapai tujuan belajar tertentu.

Menurut Dimyati dan Mudjiono (2002), pembelajaran merupakan proses yang diselenggarakan oleh guru untuk membelajarkan siswa dalam memperoleh pengetahuan, keterampilan, dan sikap.

Dalam Undang-undang No. 20 Tahun 2003 Tentang Sistem Pendidikan Nasional pasal 1 ayat 20 dinyatakan bahwa pembelajaran adalah proses interaksi peserta didik dengan pendidik dan sumber belajar pada suatu lingkungan belajar.

Pembelajaran merupakan kegiatan yang dirancang untuk membantu seseorang mempelajari suatu kemampuan dan nilai yang baru. Proses pembelajaran pada awalnya meminta guru untuk mengetahui kemampuan dasar yang dimiliki oleh siswa meliputi kemampuan dasarnya, motivasinya, latar belakang akademisnya, latar belakang ekonominya, dan lain sebagainya. kesiapan guru untuk mengenal karakteristik siswa dalam pembelajaran merupakan modal utama penyampaian bahan belajar dan menjadi indikator suksesnya pelaksanaan pembelajaran.

Dapat ditarik kesimpulan bahwa pembelajaran adalah usaha sadar dari guru untuk membuat siswa belajar, yaitu terjadinya perubahan tingkah laku pada diri siswa yang belajar, dimana perubahan itu dengan didapatkannya kemampuan baru yang berlaku dalam waktu yang relative lama dan karena adanya usaha.

Prinsip-Prinsip Pembelajaran

Menurut Sugandi, dkk (2000) menyatakan bahwa prinsip-prinsip pembelajaran adalah:

1. Kesiapan Belajar

Faktor kesiapan baik fisik maupun psikologis merupakan kondisi awal suatu kegiatan belajar. Kondisi fisik dan psikologis ini biasanya sudah terjadi pada diri 
siswa sebelum ia masuk kelas. Oleh karena itu, guru tidak dapat terlalu banyak berbuat. Namun, guru diharapkan dapat mengurangi akibat dari kondisi tersebut dengan berbagai upaya pada saat membelajarkan siswa.

2. Perhatian

Perhatian adalah pemusatan tenaga psikis tertuju pada suatu obyek. Belajar sebagai suatu aktifitas yang kompleks membutuhkan perhatian dari siswa yang belajar. Oleh karena itu, guru perlu mengetahui barbagai kiat untuk menarik perhatian siswa pada saat proses pembelajaran sedang berlangsung.

3. Motivasi

Motif adalah kekuatan yang terdapat dalam diri seseorang yang mendorong orang tersebut melakukan kegiatan tertentu untuk mencapai tujuan. Motivasi adalah motif yang sudah menjadi aktif, saat orang melakukan aktifitas. Motivasi dapat menjadi aktif dan tidak aktif. Jika tidak aktif, maka siswa tidak bersemangat belajar. Dalam hal seperti ini, guru harus dapat memotivasi siswa agar siswa dapat mencapai tujuan belajar dengan baik.

4. KeaktifanSiswa

Kegiatan belajar dilakukan oleh siswa sehingga siswa harus aktif. Dengan bantuan guru, siswa harus mampu mencari, menemukan dan menggunakan pengetahuan yang dimilikinya.

5. Mengalami Sendiri

Prinsip pengalaman ini sangat penting dalam belajar dan erat kaitannya dengan prinsip keaktifan. Siswa yang belajar dengan melakukan sendiri, akan memberikan hasil belajar yang lebih cepat dan pemahaman yang lebih mendalam.

6. Pengulangan

Untuk mempelajari materi sampai pada taraf insight, siswa perlu membaca, berfikir, mengingat, dan latihan. Dengan latihan berarti siswa mengulang-ulang materi yang dipelajari sehingga materi tersebut mudah diingat. Guru dapat mendorong siswa melakukan pengulangan, misalnya dengan memberikan pekerjaan rumah, membuat laporan dan mengadakan ulangan harian.

7. Materi Pelajaran Yang Menantang

Keberhasilan belajar sangat dipengaruhi oleh rasa ingin tahu. Dengan sikap seperti ini motivasi anak akan meningkat. Rasa ingin tahu timbul saat guru memberikan pelajaran yang bersifat menantang atau problematis. Dengan pemberian materi yang problematis, akan membuat anak aktif belajar.

\section{Ciri-Ciri Pembelajaran}

Menurut Eggen \& Kauchak dalam Soetarno (2001)menjelaskan bahwa ada enam ciri pembelajaran yang efektif, yaitu:

1. Siswa menjadi pengkaji yang aktif terhadap lingkungannya melalui mengobservasi, membandingkan, menemukan kesamaan-kesamaan dan perbedaan-perbedaan serta membentuk konsep dan generalisasi berdasarkan kesamaan-kesamaan yang ditemukan,

2. Guru menyediakan materi sebagai fokus berpikir dan berinteraksi dalam pelajaran,

3. Aktivitas-aktivitas siswa sepenuhnya didasarkan pada pengkajian,

4. Guru secara aktif terlibat dalam pemberian arahan dan tuntunan kepada siswa dalam menganalisis informasi,

5. Orientasi pembelajaran penguasaan isi pelajaran danpengembangan keterampilan berpikir, serta 
6. Guru menggunakan teknik mengajar yang bervariasi sesuai dengan tujuan dan gaya mengajar guru.

\section{Tujuan Pembelajaran}

Tujuan dari pembelajaran adalah perubahan prilaku dan tingkah laku yang positif dari peserta didik setelah mengikuti kegiatan belajar mengajar, seperti: perubahan yang secara psikologis akan tampil dalam tingkah laku yang dapat diamati melalui alat indera oleh orang lain baik tutur katanya, motorik dan gaya hidupnya.. Surya dalam Lintang (2005) mengemukakan ciri-ciri dari perubahan perilaku, sebagai berikut:

1. Perubahan yang disadari dan disengaja (intensional).

Perubahan perilaku yang terjadi merupakan usaha sadar dan disengaja dari individu yang bersangkutan. Begitujuga dengan hasil-hasilnya, individu yang bersangkutan menyadari bahwa dalam dirinya telah terjadi perubahan,misalnya pengetahuannya semakin bertambah atau keterampilannya semakin meningkat, dibandingkan sebelumdia mengikuti suatu proses belajar.

2. Perubahan yang berkesinambungan (kontinyu).

Bertambahnya pengetahuan atau keterampilan yang dimiliki pada dasarnya merupakan kelanjutan daripengetahuan dan keterampilan yang telah diperoleh sebelumnya. Begitu juga, pengetahuan, sikap dan keterampilanyang telah diperoleh itu, akan menjadi dasar bagi pengembangan pengetahuan, sikap dan keterampilan berikutnya.

3. Perubahan yang fungsional.

Setiap perubahan perilaku yang terjadi dapat dimanfaatkan untuk kepentingan hidup individu yang bersangkutan, baik untuk kepentingan masa sekarang maupun masa mendatang.

4. Perubahan yang bersifat positif.

Perubahan perilaku yang terjadi bersifat normatif dan menujukkan ke arah kemajuan.

5. Perubahan yang bersifat aktif.

Untuk memperoleh perilaku baru, individu yang bersangkutan aktif berupaya melakukan perubahan.

6. Perubahan yang bersifat pemanen.

Perubahan perilaku yang diperoleh dari proses belajar cenderung menetap dan menjadi bagian yang melekat dalamdirinya.

7. Perubahan yang bertujuan dan terarah.

Individu melakukan kegiatan belajar pasti ada tujuan yang ingin dicapai, baik tujuan jangka pendek, jangka menengah maupun jangka panjang.

8. Individu melakukan kegiatan belajar pasti ada tujuan yang ingin dicapai, baik tujuan jangka pendek, jangkamenengah maupun jangka panjang.

9. Perubahan perilaku secara keseluruhan.

Perubahan perilaku belajar bukan hanya sekedar memperoleh pengetahuan semata, tetapi termasuk memperolehpula perubahan dalam sikap dan keterampilannya.

\section{PENTINGNYA KECERDASAN EMOSIONAL SISWA DALAM PEMBELAJARAN}

Sebagian besar orang tua selalu berharap sejak kecil siswa mempunyai nilai yang bagus di sekolah. Setelah siswa lulus sekolah, mereka diharapkan untuk mendapatkan pekerjaan yang dapat membantunya untuk meraih hidup sejahtera "masa depan yang 
cerah" dan gaji yang tinggi. Banyak orang tua, bahkan para guru, berpikir bahwa nilai yang tinggi dan lulus sekolah merupakan jaminan untuk mendapatkan pekerjaan dan kesuksesan dalam karier. Kenyataan tersebut memang tidak dapat disangkal. Kemampuan dan nilai akademis yang tinggi dapat membuka banyak pintu bagi kesuksesan seseorang. Akan tetapi, kenyataannya, baik dalam dunia kerja, pribadi, maupun proses belajar mengajar, kemampuan kecerdasan emosional (emotional intelligence) sangat berperan untuk mencapai kesuksesan seseorang. Lapangan kerja yang semakin kompetitif dan spesialis, membuat tidak seorang individu atau institusi mana pun yang dapat mencapai tujuan mereka tanpa harus bekerja sama dalam tim karena setiap orang dipaksa untuk bekerja sama dengan orang lain.

Pendidikan adalah suatu usaha atau kegiatan yang dijalankan dengan sengaja, teratur dan berencana dengan maksud mengubah atau mengembangkan perilaku yang diinginkan. Sekolah sebagai lembaga formal merupakan sarana dalam rangka pencapaian tujuan pendidikan tersebut. Melalui sekolah, siswa belajar berbagai macam hal. Dalam pendidikan formal, belajar menunjukkan adanya perubahan yang sifatnya positif sehingga pada tahap akhir akan didapat keterampilan, kecakapan dan pengetahuan baru. Hasil dari proses belajar tersebut tercermin dalam prestasi belajarnya. Namun dalam upaya meraih prestasi belajar yang memuaskan dibutuhkan proses belajar.

Proses belajar yang terjadi pada individu memang merupakan sesuatu yang penting, karena melalui belajar individu mengenal lingkungannya dan menyesuaikan diri dengan lingkungan disekitarnya. Belajar merupakan proses perubahan dari belum mampu menjadi mampu dan terjadi dalam jangka waktu tertentu. Dengan belajar, siswa dapat mewujudkan cita-cita yang diharapkan. Oleh karenanya belajar akan menghasilkan perubahan-perubahan dalam diri seseorang. Untuk mengetahui sampai seberapa jauh perubahan yang terjadi, perlu adanya penilaian. Begitu juga dengan yang terjadi pada seorang siswa yang mengikuti suatu pendidikan selalu diadakan penilaian dari hasil belajarnya. Penilaian terhadap hasil belajar seorang siswa untuk mengetahui sejauh mana telah mencapai sasaran belajar inilah yang disebut sebagai prestasi belajar yaitu " Hasil yang dicapai seorang siswa dalam usaha belajarnya sebagaimana dicantumkan di dalam nilai rapornya. Melalui prestasi belajar seorang siswa dapat mengetahui kemajuan-kemajuan yang telah dicapainya dalam belajar."

Proses belajar di sekolah adalah proses yang sifatnya kompleks dan menyeluruh. Banyak orang yang berpendapat bahwa untuk meraih prestasi yang tinggi dalam belajar, seseorang harus memiliki kecerdasan intelektual yang tinggi, karena inteligensi merupakan bekal potensial yang akan memudahkan dalam belajar dan pada gilirannya akan menghasilkan prestasi belajar yang optimal. Karena hakikat inteligensi adalah kemampuan untuk menetapkan dan mempertahankan suatu tujuan, untuk mengadakan penyesuaian dalam rangka mencapai tujuan itu, dan untuk menilai keadaan diri secara kritis dan objektif.

Kenyataannya, dalam proses belajar mengajar di sekolah sering ditemukan siswa yang tidak dapat meraih prestasi belajar yang setara dengan kemampuan inteligensinya. Ada siswa yang mempunyai kemampuan inteligensi tinggi tetapi memperoleh prestasi 
belajar yang relatif rendah, namun ada siswa yang walaupun kemampuan inteligensinya relatif rendah, dapat meraih prestasi belajar yang relatif tinggi. Itu sebabnya taraf inteligensi bukan merupakan satu-satunya faktor yang menentukan keberhasilan seseorang, karena ada faktor lain yang mempengaruhi. Faktor kekuatan-kekuatan lain, diantaranya adalah kecerdasan emosional atau Emotional Quotient (EQ) yakni kemampuan memotivasi diri sendiri, mengatasi frustasi, mengontrol desakan hati, mengatur suasana hati (mood), berempati serta kemampuan bekerja sama.

Lebih lanjut dalam pasal 45 ayat (1) Setiap satuan pendidikan formal dan nonformal menyediakan sarana dan prasarana yang memenuhi keperluan pendidikan sesuai dengan pertumbuhan dan perkembangan potensi fisik, kecerdasan intelektual, sosial, emosional, dan kejiwaan peserta didik.

Kecerdasan emosional sangat penting dalam pembelajaran karena bagaimana upaya mengembangkan seorang anak agar memiliki kecerdasan intelektual yang tinggi dan sekaligus juga seorang yang sangat manusiawi memiliki kecerdasan emosi yang tinggi pula. Keseimbangan di antara kedua kecerdasan tersebut diperlukan jika menginginkan seseorang yang pandai, kreatif sekaligus manusia yang dapat berempati, yang dapat mengontrol emosinya, yang dapat memotivasi dirinya sendiri sehingga dapat mandiri, yang selalu mawas diri karena mengetahui perasaan yang ada di dalam dirinya sendiri maupun perasaan yang ada pada orang lain.

Selama ini banyak orang beranggapan bahwa jika seseorang memiliki tingkat kecerdasan intelektual yang tinggi, maka orang tersebut memiliki peluang untuk meraih kesuksesan yang lebih besar di banding seseorang yang memiliki kecerdasan intelektual dibawahnya. Namun pada kenyataannya, banyak kasus di mana seseorang yang memiliki tingkat kecerdasan intelektual yang tinggi tersisih dari orang lain yang tingkat kecerdasan intelektualnya lebih rendah. Ternyata kecerdasan intelektual yang tinggi tidak menjamin seseorang akan meraih kesuksesan. Goleman (2004) membuktikan bahwa tingkat emosional manusia lebih mampu memperlihatkan kesuksesan seseorang. Kecerdasan intelektual tidak dapat berkembang. Jika seseorang terlahir dengan kondisi kecerdasan intelektual sedang, maka kecerdasan intelektual nya tidak pernah bisa bertambah maupun berkurang. Artinya, jika seseorang terlahir dengan kecerdasan intelektualyang cukup, percuma saja dia mencoba dengan segala cara untuk mendapatkan yang superior (jenius), begitu pula sebaliknya. Berbeda dengan kecerdasan emosional yang dapat dikembangkan seumur hidup dengan belajar dan berlatih.

Kecerdasan Emosional tumbuh seiring perkembangan seseorang sejak lahir hingga meninggal dunia. Perkembangan kecerdasan emosi dipengaruhi oleh lingkungan, keluarga, dan contoh-contoh yang didapat seseorang sejak lahir dari orang tuanya. Kecerdasan Emosi menyangkut banyak aspek penting, yang agaknya semakin sulit didapatkan pada manusia modern, yaitu: empati (memahami orang lain secara mendalam), mengungkapkan dan memahami perasaan, mengendalikan amarah, kemandirian, kemampuan menyesuaikan diri, disukai, kemampuan memecahkan 
masalah antar pribadi, ketekunan, kesetiakawanan dan keramahan, serta sikap hormat.Orang dengan kecerdasan intelektual tinggi dapat terperosok ke dalam nafsu yang tak terkendali dan impuls yang meledak-ledak. Kecerdasan akademis praktis tidak menawarkan persiapan untuk menghadapi gejolak atau kesempatan yang ditimbulkan oleh kesulitan-kesulitan hidup. kecerdasan intelektual yang tinggi tidak menjamin kesejahteraan, gengsi, atau kebahagiaan hidup. Banyak bukti memperlihatkan bahwa orang yang secara emosional cakap yang mengetahui dan menangani perasaan mereka sendiri dengan baik, dan yang mampu membaca dan menghadapi perasaan orang lain dengan efektif memiliki keuntungan dalam setiap bidang kehidupan, seperti dalam hubungan dan persahabatan, ataupun dalam menangkap aturan-aturan tak tertulis yang menentukan keberhasilan dalam politik organisasi.

Orang dengan ketrampilan emosional yang berkembang baik berarti kemungkinan besar ia akan bahagia dan berhasil dalam kehidupan, menguasai kebiasaan pikiran yang mendorong produktivitas mereka. Orang yang tidak dapat menghimpun kendali tertentu atas kehidupan emosionalnya akan mengalami pertarungan batin yang merampas kemampuan mereka untuk berkonsentrasi pada karir/pekerjaan ataupun untuk memiliki pikiran yang jernih. Generasi sekarang, lebih banyak mengalami kesulitan emosional daripada generasi sebelumnya, lebih kesepian dan pemurung, lebih berangasan dan kurang menghargai sopan santun, lebih gugup dan mudah cemas, lebih impulsif dan agresif. Kemerosotan emosi tampak dalam semakin parahnya masalah-masalah sepertimenarik diri dari pergaulan atau masalah social, lebih suka menyendiri, bersikap sembunyi-sembunyi, banyak bermuram durja dan kurang bersemangat, merasa tidak bahagia, terlampau bergantung, cemas dan depresi, menyendiri, ingin sempurna, merasa tidak dicintai, dan merasa gugup.

Mempersiapkan agar anak-anak mampu dalam menghadapi dan menempuh kehidupan diperlu pendidikan kecakapan manusiawi dasariah, seperti kesadaran diri, pengendalian diri, dan empati, seni mendengarkan, menyelesaikan pertentangan dan kerja sama. Kendati terdapat kendali sosial, dari waktu ke waktu nafsu seringkali menguasai nalar. Perlu adanya keseimbangan antara kecerdasan rasional dan kecerdasan emosional. Pelatihan untuk menyatakan perasaan negatif (marah, frustrasi, kecewa, depresi, cemas) menjadi amat penting. Pelampiasan yang tidak tepat justru menambah intensitas, bukan mengurangi. Cara berpikir menentukan cara merasa, oleh karenanya berpikir positif sangatlah diperlukan. Ketekunan, kendali dorongan hati dan emosi, penundaan pemuasan yang dipaksakan kepada diri sendiri demi suatu sasaran, kemampuan untuk mengetahui bagaimana perasaan orang lain (empati), dan manajemen diri merupakan hal yang dapat dipelajari.

Pengalaman dan pendidikan di masa kanak-kanak akan sangat menentukan dasar pembentukan ketrampilan sosial dan emosional. Untuk itulah perlu membiasakan anak untuk berpikir kritis, mengajar anak untuk lebih hati-hati, lebih teliti terhadap apa yang dipikirkan. Mengajar anak memecahkan masalah dengan mencari solusi yang terbaik. berarti mengajarkan anak membuat strategi di dalam menghadapi berbagai masalah secara menyeluruh, mengajar anak menentukan pilihan, solusi dan strategi. Hal ini 
dapat dicapai dengan membiasakan anak mengambil keputusan sendiri, brainstorming, dan metakognisi (berpikir tentang berpikir) dan sebagainya. Karena sifatnya meningkatkan kemampuan berpikir maka di dalam kegiatan tersebut sekaligus meningkatkan kemampuan emosi. Dalam kegiatan brainstorming misalnya, guru melatih anak untuk mengontrol emosi dan sekaligus meningkatkan keterampilan interpersonal atau berpikir melihat berbagai kemungkinan atau alternatif. Dan yang terpenting adalah di dalam upaya menyeimbangkan antara kemampuan intelektual dan kemampuan emosional perlu adanya kecerdasan spiritual sebagai fungsi kontrol. Dengan demikian kecerdasan intelektual dalam arti intelligensi yang sifatnya multipel dan kecerdasan emosi yaitu kehidupan emosi yang meliputi berbagai domain, dapat bergandengan dalam upaya pengembangan anak, baik di dalam studi maupun dalam menatap masa depannya.

\section{Manfaat Kecerdasan Emosi bagi peserta didik}

Melalui kecerdasan emosi diharapkan semua unsur yang terlibat dalam pendidikan dan pembelajaran dapat memahami diri dan lingkungannyasecara tepat, memiliki rasa percaya diri, tidak iri hati, tidak dengki, tidak cemas, tidak takut, murung, tidak mudah putus asa, dan tidak mudah marah.

Menurut Mulyasa (2007) manfaat kecerdasan emosi bagi peserta didik:

1. Jujur, disiplin, dan tulus pada diri sendiri, membangun kekuatan dan kesadaran diri, mendengarkan suara hati, hormat dan tanggung jawab.

2. Memantapkan diri, maju terus, ulet, dan membangun inspirasi secara berkesinambungan.

3. Membangun watak dan kewibawaan, meningkatkan potensi, dan mengintegrasikan tujuan belajar ke dalam tujuan hidupnya

4. Memanfaatkan peluang dan menciptakan masa depan yang lebih cerah.

Sedangkan cara mengembangkan kecerdasan emosi dalam pembelajaran:

1. Menyediakan lingkungan yang kondusif.

2. Menciptakan iklim pembelajaran yang demokratis.

3. Mengembangkan sikap empati, dan merasakan apa yang sedang dirasakan oleh peserta didik.

4. Membantu peserta didik menemukan solusi dalam setiap masalah yang dihadapinya.

5. Melibatkan pesrta didik secara optimal dalam pembelajaran, baik secara fisik, sosial maupun emosional.

6. Merespon setiap perilaku peserta didik secxara positif dan menghindari respon yang negative.

7. Menjadi teladan dalam menegakkan aturan dan disiplin dalam pembelajaran.

\section{PENUTUP}

Kecerdasan dapat dipahami sebagaikemampuan sesorang untuk melakukan sesuatu. Kemampuan manusia seringkali hanya diukur dari segi kognitif semata, yaitu hal-hal yang dapat diukur dengan angka.Kenyataannya, dalam proses belajar mengajar 
di sekolah sering ditemukan siswa yang tidak dapat meraih prestasi belajar yang setara dengan kemampuan inteligensinya. Ada siswa yang mempunyai kemampuan inteligensi tinggi tetapi memperoleh prestasi belajar yang relatif rendah, namun ada siswa yang walaupun kemampuan inteligensinya relatif rendah, dapat meraih prestasi belajar yang relatif tinggi. Itu sebabnya taraf inteligensi bukan merupakan satu-satunya faktor yang menentukan keberhasilan seseorang, karena ada faktor lain yang mempengaruhi. Faktor kekuatan-kekuatan lain, diantaranya adalah kecerdasan emosional yakni kemampuan memotivasi diri sendiri, mengatasi frustasi, mengontrol desakan hati, mengatur suasana hatiberempati serta kemampuan bekerja sama.

Dalam proses belajar siswa, kedua inteligensi itu sangat diperlukan. Kecerdasan intelektual tidak dapat berfungsi dengan baik tanpa partisipasi penghayatan emosional terhadap mata pelajaran yang disampaikan di sekolah. Namun biasanya kedua inteligensi itu saling melengkapi. Keseimbangan antara kecerdasan intelektual dan kecerdasan emosional merupakan kunci keberhasilan belajar siswa di sekolah. Pendidikan di sekolah bukan hanya perlu mengembangkan kecerdasan intelektual yaitu model pemahaman yang lazimnya dipahami siswa saja, melainkan juga perlu mengembangkan kecerdasan emosional siswa.

Untuk mengembangkan dan mengoptimalkan kecerdasan emosional yang berperan dalam keberhasilan siswa baik di sekolah maupun di lingkungan sekitarnya, maka disarankan kepada pihak sekolah terutama guru-guru pengajar agar memasukkan unsur-unsur kecerdasan emosioal dalam menyampaikan materi serta melibatkan emosi siswa dalam proses pembelajaran.

\section{DAFTAR PUSTAKA}

Aunurrahman. 2010. Belajar dan Pembelajaran, Bandung: Alfabeta

Agustian, AryGinanjar. 2001.Rahasia Sukses Membangun Kecerdasan Emosi dan Spiritual (ESQ). Jakarta: Penerbit Arga.

Dimyati, dan Mujiono. 2002. Belajar dan Pembelajaran. Jakarta: Rineka Cipta.

Goleman, Danil. 1998. What Makes a Leader?Best of Havard Business Review, halaman 82 - 91

Goleman, Daniel. (2002). Emotional Intelligence Kecerdasan Emosional Mengapa EQ Lebih Penting Daripada IQ. Jakata: PT Gramedia Pustaka Utama.

Goleman, Daniel. (2000),Working with Emotional Intelligence (terjemahan). Jakarta:

PT. Gramedia Pustaka Utama

http://belajarpsikologi.com/pengertian-kecerdasan-emosional-eq/\#ixzz1funsCXk8

http://belajarpsikologi.com/cara-meningkatkan-kecerdasan-emosi-eq/\#ixzz1fumR4o4r

http://belajarpsikologi.com/arti-penting-kecerdasan-emosi-eq/\#ixzz1fumkQVtW

http://belajarpsikologi.com/pengertian-emosi/\#ixzz1funY8E8B

http://bambangsigitwidodo.blogspot.com/2010/05/pentingnya-kecerdasan-emosionaldalam.html

http://xerma.blogspot.com/2013/08/pengertian-pembelajaran.html

Mulayasa, E. 2007. Menjadi Guru Profesional. Bandung: Remaja Rosdakarya. 
Sanjaya, Wina. 2008. Perencanaan dan Desain Sistem

Pembelajaran.Bandung. Kencana Prenada Media Group

Sugandi, Achmad, dkk. 2000. Belajar dan Pembelajaran.Semarang, IKIP Press.

UU No. 20 Tahun 2003 tentang Sistem Pendidikan Nasional 
